\title{
RAIMUNDO LÚLIO, A IDADE MÉDIA GLOBAL E O ENSINO DE HISTÓRIA: PERSPECTIVAS DE ABORDAGEM
}

Ramon Llull, the Global Middle Ages, and the Teaching of History: possible approaches 


\title{
RESUMO
}

Detratores e enaltecedores da Idade Média concordam com o fato de que ela é uma etapa do passado da Europa. O objetivo deste artigo é superar essa perspectiva, articulando a Idade Média global ao ensino de história. Para isso, algumas categorias, como integração, conexão e interação, serão mobilizadas para a compreensão de uma experiência de globalidade. Seguiremos os passos de Raimundo Lúlio (c. 1232-1316), filósofo maiorquino cuja extensa e multifacetada obra tem sido cada vez mais pesquisada e traduzida no Brasil. A trajetória e o pensamento de Lúlio, contudo, foram pouco aproveitados no ensino de história. Com o propósito de oferecer caminhos e possibilidades, analisaremos o potencial de determinadas histórias em quadrinhos sobre o filósofo e adaptações infantojuvenis do corpus luliano, indicando perspectivas de abordagem para a atuação docente e elaborando materiais didáticos.

\section{PALAVRAS-CHAVE}

Raimundo Lúlio. Idade Média global. Ensino de história.

\begin{abstract}
Those who detract and those who extol the Middle Ages agree that it is a phase in Europe's past. The purpose of this article is to move beyond this perspective, linking the Global Middle Ages to the Teaching of History. For this, some concepts such as integration, connection, and interaction will be used to understand an experience of globality. We will follow the trajectory of Ramon Llull (ca. 1232-1316), Majorcan philosopher whose extensive and multi-faceted body of work has been increasingly translated and researched in Brazil. However, teachers of History rarely use Llull's trajectory and ideas in their teaching. Aiming to offer paths and possibilities, we will analyze the potential of some comics about the philosopher and of some children's and youth adaptations of the Lullian corpus, indicating teaching approaches and creating teaching materials.
\end{abstract}

\section{KEYWORDS}

Ramon Llull. Global Middle Ages. Teaching of History. 
m pleno século XXI, duas visões antagônicas sobre a Idade Média ainda povoam o imaginário popular brasileiro. Por um lado, ela é sinônimo de trevas, barbárie e ignorância. Notamos tal percepção, criada por renascentistas e iluministas, em noticiários e livros didáticos, que já apontaram uma decadência cultural naquele tempo, em virtude do controle "perverso" da Igreja (PEREIRA, 2009, p. 125). Por outro, designa um mundo glorioso, um passado nostálgico no qual cavaleiros corajosos lutavam em nome de um catolicismo civilizador. Essa imagem, elaborada pelos românticos, também vê aquele milênio como o momento das origens das nações europeias. As redes sociais estão repletas de discursos daqueles que se consideram herdeiros dessas tradições. Por elas, alguns até gritam Deus vult...

Detratores e enaltecedores da Idade Média, porém, concordam com o fato de que ela é uma etapa do passado da Europa. Esse Medievo, que ainda é ocidental, latino, cristão e branco, se consolidou no pensamento europeu no século XIX - não por acaso, num período "impregnado do veneno do nacionalismo étnico" (GEARY, 2005, p. 27). Mesmo no ambiente acadêmico, falar em Idade Média é se referir quase sempre ao "Ocidente europeu". Uma parte dessa inclinação historiográfica recebeu influência dos recortes espaciais preferidos por medievalistas franceses, sobretudo da Escola dos Annales, que foram amplamente traduzidos e são presença constante nos cursos de história e em bibliotecas universitárias brasileiras. Por aqui, Marc Bloch, Georges Duby e Jacques Le Goff fizeram escola.

Encontramos essa tradição em nosso ensino básico. Nesse importante ambiente formativo, a época medieval se resume muitas vezes à história da Europa ocidental, com ênfase nos territórios das atuais França, Inglaterra, Alemanha e Itália; seu ensino tem um perfil "colonizado" (MACEDO, 2003, p. 115-116). No fim de 2015, tal aspecto esteve posicionado numa fronteira perigosa, na linha de frente, quando foi condenado pelos historiadores que compuseram a primeira versão da Base Nacional Comum Curricular (BNCC), lançada pelo Ministério da Educação (MEC). A decisão deles foi radical. Em nome de um suposto combate ao eurocentrismo e ao esquema quadripartite, os autores do documento excluíram o Medievo e a Antiguidade dos currículos escolares.

Com razão, a decisão logo foi criticada. Ora, a BNCC pregava uma história nacionalista e presentista, ignorando as recentes epistemologias que renovam o conhecimento histórico na pesquisa e no ensino. Nesse início de século XXI, a medievalística brasileira está muito atenta a essas tendências. Chama a atenção o diálogo com uma perspectiva historiográfica em particular, a história global, ${ }^{1} \mathrm{com}$ acentuada popularização após o fim da Guerra Fria e determinada a enfrentar dois inimigos: o eurocentrismo e o internalismo metodológico (CONRAD, 2019, p. 11-14). Ela já atraiu alguns de nossos medievalistas a ponto de uma "Idade Média global", nos

\footnotetext{
${ }^{1}$ A história global trata da "mobilidade e do intercâmbio [de coisas, pessoas, ideias e instituições], nos processos que transcendem as fronteiras e as barreiras [...] O objetivo não é o de escrever a história integral do planeta. É antes a procura de um modo de escrever história de espaços demarcados (ou seja, não 'globais'), mas com a consciência da existência de conexões e de condições estruturais ao nível global". Todavia, "qualquer estudo de história global depende de algum conhecimento básico acerca do grau, escopo e qualidade da integração a grande escala" (CONRAD, 2019, p. 15-16; 24; 124).
} 
últimos dois anos, ser observada em temáticas de congressos, disciplinas em cursos de história, dossiês de periódicos e publicações sistematizadoras e propositivas. ${ }^{2}$

No âmbito internacional, há um esforço para alterar o foco das publicações (FRANKOPAN, 2019), o que impulsionou a criação das revistas The Medieval Globe (2014), Medieval Worlds (2015) e Journal of Medieval Worlds (2019). No entanto, a própria nomenclatura Idade Média global causa desconforto. Para uns, ela é muito ampla e vaga; para outros, o eurocentrismo é um elemento intrínseco de tudo aquilo que é "medieval". Em vez disso, preferem o rótulo "era da intensificação global" (MOORE, 2016, p. 92, tradução nossa). De todo modo, algumas propostas definiram coerentemente as principais características desse jovem conceito, entre as quais múltiplos centros, fronteiras porosas e sociedades plurais, complexas e diversas, com a presença do comércio de longa distância, migrações (forçadas ou não), impérios multiétnicos e transmissão de formas culturais e religiões universais em grandes áreas. Ainda que a Eurásia seja o espaço preferido dos pesquisadores, discussões para a incorporação de outros continentes têm sido constantes (HOLMES; STANDEN, 2015, p. 106-107).

$\mathrm{Na}$ verdade, repensar os limites espaciais da Idade Média implica reavaliar suas próprias balizas cronológicas. Vejamos brevemente seu terminus a quo. Alguns estudiosos indicaram a insuficiência de considerar, num quadro de conectividade global, o fim do Império Romano do Ocidente (século V) como o momento ideal para marcar o início daquele período. Como divisa mais plausível, sugeriram, por exemplo, a erupção do vulcão Ilopango (536 d.C.), em El Salvador, cujo poderoso impacto não afetou apenas a Mesoamérica; sabemos, hoje, que ele desencadeou "um efeito climático em cascata de longo prazo na Afro-Eurásia e, portanto, teve uma influência indireta, mas fundamental, na história de grandes partes do globo no início do Medievo" (HERMANS, 2020, p. 5, tradução nossa).

Com a história global, podemos atualizar o conceito de Idade Média, descolonizando-o da apropriação europeia e reintegrando-o à história do mundo (SILVEIRA, 2019, p. 214). O objetivo deste artigo é articular o Medievo ao ensino de história. Para isso, algumas categorias, como integração, conexão e interação, foram mobilizadas para a compreensão de uma experiência de globalidade. Seguimos os passos de Raimundo Lúlio, filósofo maiorquino cuja extensa e multifacetada obra tem sido cada vez mais pesquisada e traduzida no Brasil. A trajetória e o pensamento de Lúlio, contudo, foram pouco aproveitados no ensino escolar. De forma específica, analisamos o potencial de determinadas histórias em quadrinhos (HQs) sobre o pensador e adaptações infantojuvenis do corpus luliano, indicando perspectivas de abordagem para a atuação docente e elaborando materiais didáticos.

\section{RAIMUNDO LÚLIO EM SALA DE AULA}

Nascido em Maiorca por volta de 1232, ano em que o rei Jaime I de Aragão conquistou completamente a ilha dos almôadas, Raimundo Lúlio frequentou a corte aragonesa durante sua juventude, com predileção pelos costumes trovadorescos. Em

\footnotetext{
${ }^{2}$ Respectivamente, "III Jornada de Estudos Medievais: Idade Média e História Global" (2019), evento promovido pelo Leme (USP); "História Global da Idade Média", disciplina ministrada por Paulo Pachá na UFRJ (2019); Bayard e Bovo (2020); Silva (2020); Silveira (2019).
} 
torno de 1263, ocorreu uma reviravolta em sua vida, quando relatou ter visto cinco imagens de Jesus crucificado e, logo depois, abandonou família e bens para seguir o ideal apostólico e escrever um livro que "fosse o melhor do mundo contra os erros dos infiéis" (LÚLIO, 2004, I, § 6, p. 58). ${ }^{3}$ Para isso, estudou diversos conteúdos, como gramática, teologia e filosofia, e viajou incessantemente. Esteve nos maiores centros de peregrinação do cristianismo (Santiago de Compostela, Rocamadour, Roma e, talvez, Jerusalém), em relevantes postos comerciais mediterrânicos (Barcelona, Marselha, Pisa, Nápoles, Gênova, Sicília e Chipre), em renomados núcleos intelectuais (Montpellier e Paris), na nova sede do papado (Avignon) e em regiões islâmicas (Bugia e Túnis) e ortodoxas (Rodes e Ayas).

Durante algumas dessas viagens, Lúlio se encontrou com personalidades poderosas (papas, reis, príncipes) e procurou convencê-las a executar projetos, como a fundação de escolas para o ensino do árabe e de outras línguas orientais aos pregadores cristãos. Prolífico, polígrafo e poliglota, compôs quase trezentas obras, que abordam conhecimentos filosóficos, teológicos, científicos, políticos, morais etc. Foi um dos autores medievais que mais escreveram, com textos em latim, árabe e catalão - sendo, aliás, um dos primeiros a produzir filosofia em vernáculo. Suas obras revelam um pensamento enciclopédico que influenciou autores modernos como Giordano Bruno e Leibniz (HILLGARTH, 2018, p. 52). Seus principais esforços eram direcionados à conversão do "outro", sobretudo dos muçulmanos, crentes com os quais ele deparava desde a infância. Mantendo-se laico, morreu provavelmente em 1316, com cerca de 84 anos. Vejamos como ele próprio se definia:

Eu fui um homem casado, tive filhos, era discretamente rico, lascivo e mundano. Tudo deixei de bom grado para me dedicar a fomentar a honra de Deus, o bem público e exaltar a santa fé. Aprendi árabe e fui muitas vezes pregar entre os sarracenos; por causa da fé fui preso, encarcerado e surrado. Quarenta e cinco anos eu trabalhei para mover a Igreja e os príncipes cristãos ao bem público. Agora sou velho, agora sou pobre, mas ainda tenho o mesmo propósito e o terei até a morte, se Deus quiser (LÚLIO, 2010, Prólogo, 12, p. 320).

Na Espanha, especialmente na Catalunha e nas Ilhas Baleares, múltiplas ações já divulgaram a figura de Raimundo Lúlio entre o grande público. Esse processo alcançou o ápice durante o Any Llull (2015-2016), que marcou as comemorações do sétimo centenário de sua morte, quando vários eventos e projetos foram realizados, muitos destinados ao público infantojuvenil. Um deles, a plataforma virtual Enllulla't, apresenta a trajetória do filósofo com base em nove unidades didáticas (2016). A vida e a obra de Lúlio também foram debatidas em colégios espanhóis, como La Salle de Palma, em Maiorca, onde especialistas e alunos organizaram uma exposição em 2016 (EL HISTORIADOR, 2016). Ainda naquele ano, três escolas maiorquinas - La Salle de Palma, Col-legi Sant Francesc e Escola Catòlica de les Illes Balears - receberam a visita do cantor Guillem Sansó (VISITA, 2016). Ele apresentou o espetáculo El Joglar

\footnotetext{
${ }^{3}$ Essa é uma referência à Arte luliana, um método filosófico, uma ciência universal.
} 
Pau i Ramon Llull, com atividades musicais e teatrais, paralelamente à atuação dos professores, que usaram um material composto por sete unidades.

No Brasil, a proposta de inserir as obras de Lúlio no ensino escolar apareceu numa publicação de 2003. Nela, o professor José Rivair Macedo indicou o Livro das bestas - alegoria da sociedade redigida pelo filósofo - como um exemplo de literatura medieval que poderia ser aplicado com sucesso em sala de aula. Por outro lado, como uma experiência concreta, localizamos apenas um caso publicizado: a dissertação de mestrado defendida por Natasha Nickolly Mateus na Universidade Estadual do Maranhão (UEMA), em 2018, sob a orientação de Adriana Zierer. O principal resultado desse trabalho, o livro paradidático Ramon Llull e a Idade Média, chegou a ser usado em escolas públicas de São Luís. Dividido em seis capítulos, o material contém fontes medievais, mapas, glossários, indicações de filmes, exercícios etc.

\section{RAIMUNDO LÚLIO EM HQS E ADAPTAÇÕES INFANTOJUVENIS: PERSPECTIVAS DE ABORDAGEM}

Do ponto de vista pedagógico, utilizamos diferentes materiais para atividades lúdico-educativas nas aulas de história. Como sabemos, há muito tempo, importantes teóricos reconheceram que é "enorme a influência do brinquedo no desenvolvimento de uma criança" (VIGOTSKY, 2007, p. 112). Exploramos esse potencial com a inclusão de mecanismos que otimizam algumas formas de cognição, principalmente com o exercício do raciocínio lógico e abstrato. Trabalhamos ainda com a educação histórica de acordo com Peter Lee (2001), para quem os docentes precisam explicar diretamente às crianças não só os "conceitos substantivos" - como revolução, Império e feudalismo -, mas também os de "segunda ordem" - como fonte, representação e anacronismo. ${ }^{4} \mathrm{Na}$ última categoria, aquela que, segundo ele, confere "consistência à disciplina", incluímos conceitos como integração, conexão e interação, que adequamos à linguagem escolar.

Hoje em dia, o ensino básico conta com o auxílio de múltiplos recursos, como cinema, músicas, jogos, animações, histórias em quadrinhos etc. As HQs, a "nona arte", são narrativas visuais que surgiram no século XIX, porém enfrentaram vigorosos preconceitos e só começaram a aparecer no ensino brasileiro nas últimas décadas (VERGUEIRO; RAMOS, 2009, p. 9-42). Seria difícil algum educador negar hoje que elas têm uma frutífera função pedagógica, com ampla aceitação e capaz de exercitar o raciocínio lógico de forma prazerosa. Nas aulas de história, os quadrinhos podem facilitar o entendimento de noções como tempo e memória, servindo ainda para ilustrar o cotidiano das sociedades pretéritas ou serem estudados como registro do período no qual foram produzidos. Se um anacronismo for verificado, teríamos outro conceito para ser debatido (VILELA, 2014).

Em relação ao período medieval, podemos problematizar estereótipos, clichês e maniqueísmos presentes em muitos quadrinhos (LANGER, 2009, p. 3-5). Ao fim e ao cabo, as HQs com ambientação histórica são uma "representação" do passado, objetos propícios para despertar o interesse dos educandos e auxiliar na compreensão

\footnotetext{
4 "Conceitos substantivos são os que se referem a conteúdos da História [...]. Conceitos de segunda ordem são os que se referem à natureza da História” (LEE, 2001, p. 20).
} 
do conteúdo. A partir de agora, apontamos algumas orientações metodológicas para a incorporação de duas HQs sobre Lúlio: Auca de Ramon Llull (2003) e Ramon Llull, un home fantàstic (2016). O primeiro material teve as legendas adaptadas para o português e encontra-se disponível on-line; o segundo, publicado na revista Cavall Fort, está em catalão, razão pela qual suas legendas devem ser traduzidas. Esteticamente, ambos se inspiraram por vezes em mapas e em iluminuras medievais, suas cores, figuras e traços.

Na Auca de Ramon Llull, que conta com 48 cenas, as legendas em catalão e português se valeram da rima para contar a história do filósofo, do nascimento à morte. Há um claro esforço para tornar essa HQ familiar ao público infantil, tanto que o protagonista de uma das obras lulianas, Blaquerna, aparece fantasiado de Super-Homem (quadrinho 20). Numa leitura em conjunto (professor-aluno), a noção de tempo e sua passagem podem ser trabalhadas, com a observação da trajetória quase secular de Lúlio, seja nas legendas - por exemplo, "Quando setenta anos completou, / Para a Terra Santa e Armênia Ramon viajou" (quadrinho 36) -, seja nas imagens do filósofo, que "envelhece" ao longo das cenas. Tal peculiaridade é notada em sua barba, que se torna branca após o quadrinho 15. A HQ ainda representa a peregrinação compostelana e a expansão cristã em al-Andalus (Reconquista?), ${ }^{5}$ servindo como ponto de partida para a discussão desses temas em sala de aula.

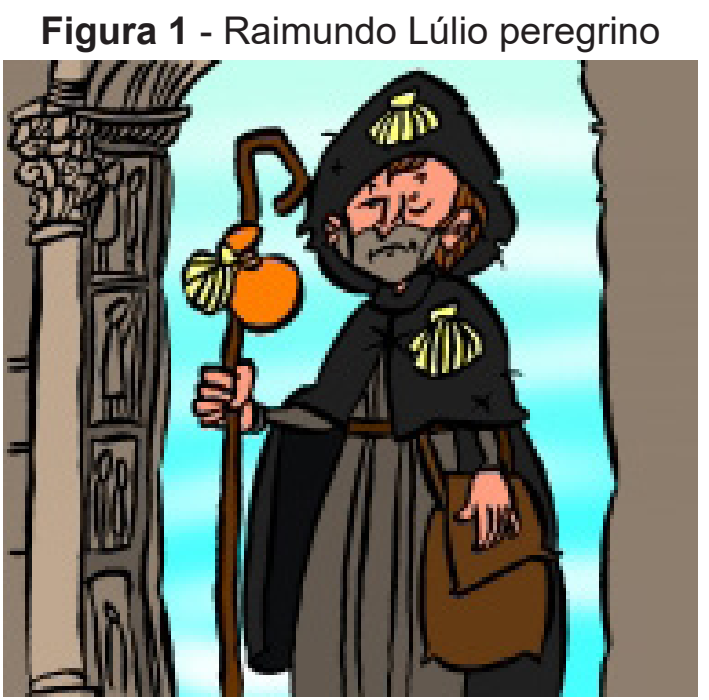

Fonte: Auca de Ramon Llull (2003), quadrinho 8. Ilustração: Jaume Gubianas. Adaptação do texto: Tatyana Nunes Lemos. Legenda: Para São Jaime iniciou sua peregrinação, / Levando seu cajado, sua bolsa e seu surrão.

\footnotetext{
${ }^{5}$ Embora seja popular, o conceito de "Reconquista" deve ser usado com todas as ressalvas possíveis. Ele nasceu na Espanha do século XIX, com uma carga ideológica nacionalista que não desapareceu após o fim do regime franquista (1975). Nessa leitura mítica do passado, a nação católica espanhola teria se forjado ao longo de uma secular e contínua guerra de libertação contra os muçulmanos, invasores estrangeiros que tinham construído uma "anti-Espanha" (al-Andalus) ilegítima e catastrófica (GARCÍA SANJUÁN, 2019).
} 
Figura 2 - A Reconquista hispânica

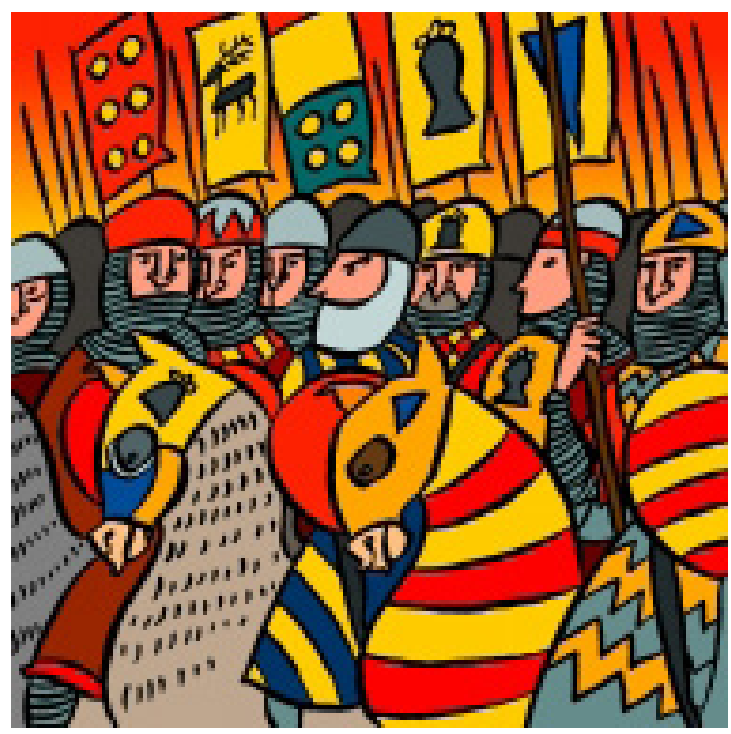

Fonte: Auca de Ramon Llull (2003), quadrinho 2. Ilustração: Jaume Gubianas. Adaptação do texto: Tatyana Nunes Lemos. Legenda: Eram tempos de guerra e de reconquista, / E Jaime I era o rei expansionista.

Para além dessa atenção ao protagonismo cristão, devemos avaliar o que essa narrativa quadrinística não expõe - por exemplo, os movimentos islâmicos, como as campanhas dos merínidas do Magreb, que cruzaram o estreito de Gibraltar (1275) e interferiram politicamente na Península Ibérica até 1340. Portanto, precisamos examinar a representação dos muçulmanos nessa $\mathrm{HQ}$, material que, como qualquer outro, pode carregar estereótipos e anacronismos. Algumas de suas escolhas de vestimenta (turbante), montaria (dromedário) e arquitetura (arco de ferradura), por exemplo, revelam elementos que não são exclusivos dos muçulmanos (quadrinhos 13, 30, 31 e 40). Temos aí um momento bastante pertinente para o professor verificar e desconstruir possíveis estigmas e preconceitos religiosos que estejam presentes em seu alunado - o Islã como sinônimo de terrorismo é um deles.

Figura 3 - Raimundo Lúlio e os muçulmanos

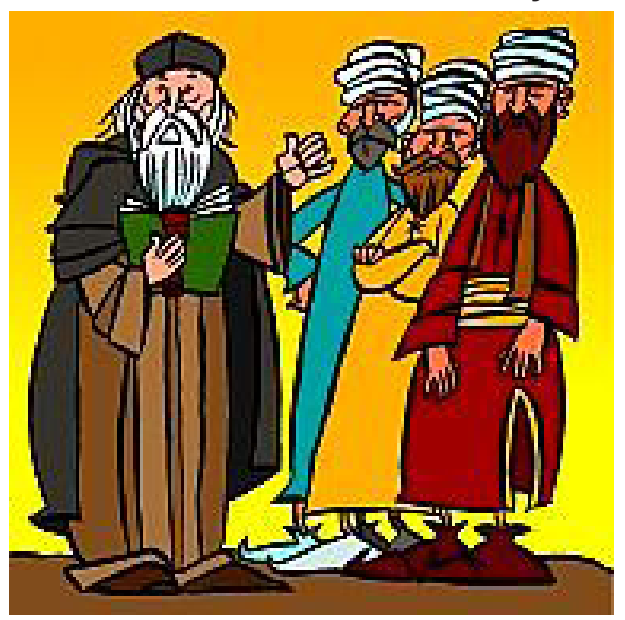

Fonte: Auca de Ramon Llull (2003), quadrinho 30. Ilustração: Jaume Gubianas. Adaptação do texto: Tatyana Nunes Lemos. Legenda: Foi a Túnis tentar convencer / Os adversários que não queriam crer. 
Ainda com base na Auca, que cita locais como Nápoles, Bugia e Túnis, sugerimos uma oficina para a produção de um mapa com as viagens de Raimundo Lúlio pelo Mediterrâneo, como fizeram os alunos do colégio La Salle de Palma (ELHISTORIADOR, 2016). Seja qual for o suporte, o itinerário luliano nos ajuda a compreender uma faceta pouco estudada no ensino escolar: o Mediterrâneo medieval. Aqui, podemos dialogar com a história global, destacando interações e conectividades entre os diversos povos - aragoneses, árabes, berberes, bizantinos, genoveses, judeus etc. - que viveram na bacia mediterrânica. Trata-se de uma história de encontros (violentos ou não), redes de alianças políticas e trocas comerciais e culturais num integrado cenário afro-euroasiático, em que transitaram mercadores, peregrinos, escravos, guerreiros, embaixadores, missionários, refugiados, entre outros. Naquele ambiente, as relações entre diferentes religiões, culturas e etnias, intensas em territórios como a Península Ibérica, a Sicília e o sul da Itália, podem ser articuladas à luz da trajetória de Lúlio. Essa proposta compõe uma renovada história do Mediterrâneo medieval, que deve aparecer com mais frequência não somente nas universidades e nas produções historiográficas (ABULAFIA, 2011), ${ }^{6}$ mas também nas escolas e nos livros didáticos.

Figura 4 - O Mediterrâneo de Raimundo Lúlio

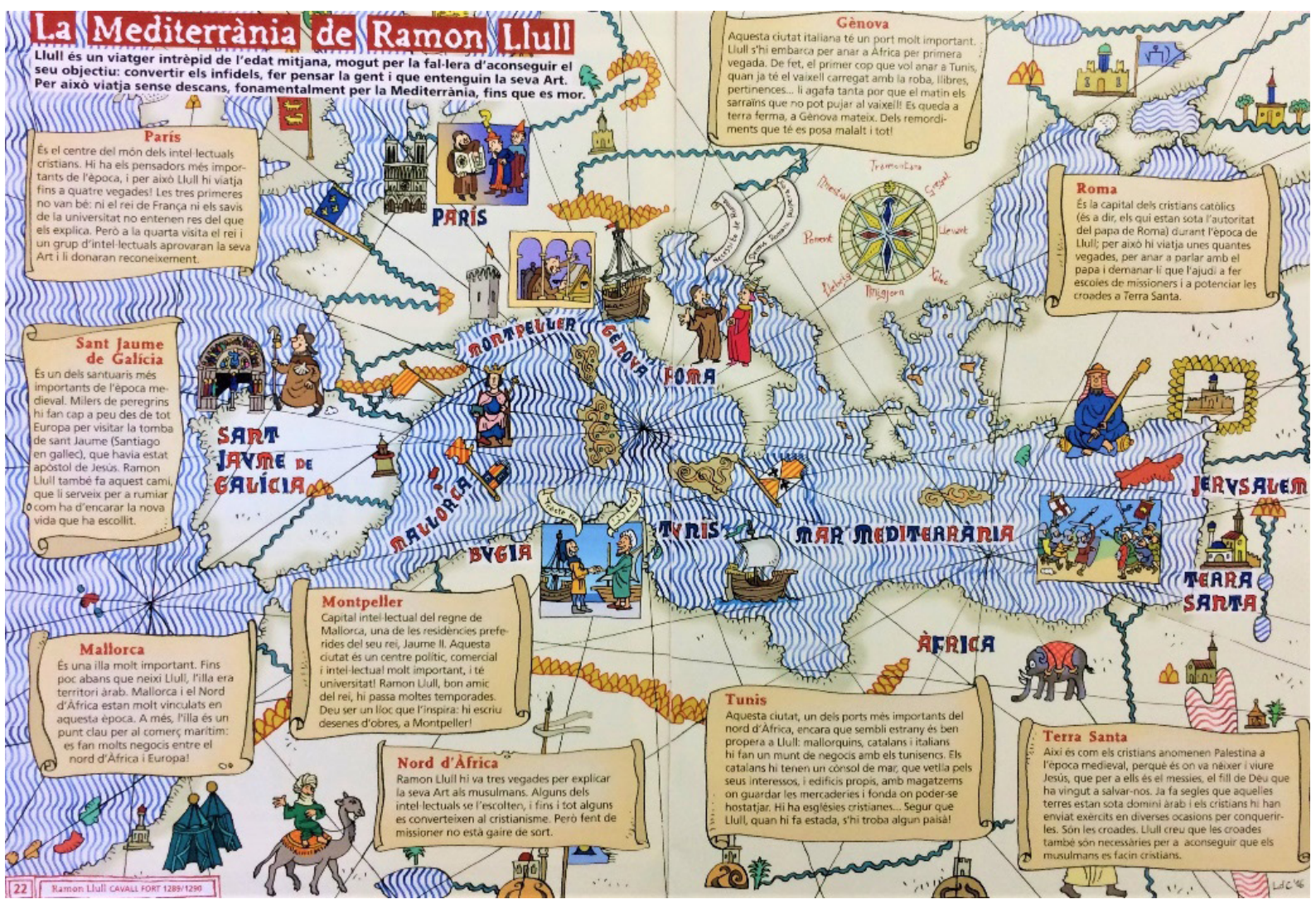

Fonte: revista Cavall Fort (2016, p. 22-23). Ilustração: Laura de Castellet.

\footnotetext{
${ }^{6}$ Em português, destacamos uma recente publicação organizada por Almeida e Della Torre (2019). Esse estudo se opõe à tese clássica de Henri Pirenne, que via o Mediterrâneo como um espaço sem conexões e interações, uma barreira entre cristãos e muçulmanos durante boa parte do Medievo. Mais do que isso, a organizadora da obra advoga pela "reincorporação de toda a bacia do Mediterrâneo à representação da Idade Média" (2019, p. 344).
} 
De forma lúdica, o mapa acima - retirado da revista Cavall Fort - contribui para essa discussão. A julgar por certos detalhes, ele se inspirou claramente, mas sem o referenciar, numa seção do célebre Atlas Catalão (Ms. Esp. 30), ${ }^{7}$ composto pelo judeu maiorquino Abraão Cresques (1375). Pode-se averiguar, por comparação com o próprio atlas medieval, quanto de historicidade foi obtido, além de problematizar a exposição dos elementos com as seguintes perguntas aos discentes: o que thes chamou a atenção no mapa? Há algum estereótipo nele? É possível relacioná-lo ao conteúdo do livro didático ${ }^{8} \mathrm{Em}$ tempos cada vez mais "visuais", saber interpretar uma imagem se tornou uma necessidade quando o professor tem a oportunidade de encaminhar criticamente um debate sobre a temática. Ainda que seja uma recriação cartográfica moderna, o material pode funcionar para atrair a curiosidade dos estudantes e contribuir para o processo de aprendizagem.

Essa focalização da bacia mediterrânica medieval é uma recomendação tanto de recentes tendências historiográficas quanto da terceira versão da BNCC (2017). Nesse caso, o documento do MEC estabeleceu a Idade Média como conteúdo obrigatório do $6^{\circ}$ ano do Ensino Fundamental, indicando "o Mediterrâneo como espaço de interação entre as sociedades da Europa, da África e do Oriente Médio" (BRASIL, 2017, p. 420). A adoção dessa perspectiva, entretanto, requer atenção, pois o eurocentrismo não deve ser substituído por um "mediterraneocentrismo". Em verdade, o estudo do Medievo precisa abranger cenários "globais", entre eles o mundo islâmico, com o qual Raimundo Lúlio mantinha relações diretas e profundas. Outro ponto a ser salientado é que as interações mediterrânicas e asiáticas citadas pela BNCC não se restringiam ao Oriente Médio.

Para comprovar isso, ancoramo-nos outra vez na história global, com a verificação do contexto analisado dentro do esquema macro (BORGOLTE, 2017, p. 79). ${ }^{9}$ A partir do início do século XIII, tem-se a formação da maior entidade política vista até então, o Império Mongol, que dominou uma significativa parte da Eurásia. À oeste, os mongóis atingiram a Europa central, com triunfos na Polônia e na Hungria (1241). À leste, a fulminante expansão só foi interrompida nas tentativas fracassadas de conquistar o Japão (1274 e 1281) e Java (1293). Entre suas façanhas com profundos impactos, estava a destruição do Califado Abássida de Bagdá (1258) e da Dinastia Song na China (1279). O Império Mongol favoreceu os interesses dos mercadores, a ponto de alguns historiadores indicarem aí o nascimento de um "sistema mundial" (ABU-LUGHOD, 1989) e o começo da globalização (GARCÍA ESPADA, 2017, p. 239310). De fato, caminhos como a famosa Rota da Seda se tornaram mais seguros, beneficiando a integração por meio de empreendimentos (políticos, comerciais, religiosos etc.) que partiam da Europa em direção à China, como aqueles da família Polo e dos missionários franciscanos e dominicanos. ${ }^{10}$

\footnotetext{
${ }^{7}$ Esse também é o caso da Auca de Ramon Llull (quadrinho 13), que apresenta um muçulmano montado num dromedário, figura claramente inspirada no Atlas Catalão (Cf. CRESQUES, 1375).

${ }^{8} \mathrm{O}$ próprio Atlas Catalão já foi utilizado em recentes livros didáticos (APOLINÁRIO, 2014, p. 67).

${ }^{9} \mathrm{~A}$ história global focaliza "contatos culturais e interações em nível local ou regional. [...]. No entanto, também requer situar tal contexto no esquema maior das coisas. Histórias globais da Idade Média, portanto, não estão apenas interessadas em contatos interculturais, mas também, e mais ainda, em redes transculturais" (BORGOLTE, 2017, p. 79, tradução nossa).

${ }^{10}$ Aqui, ainda é essencial considerar as "redes" que "moldaram a conectividade do mundo durante séculos. Até mesmo os grandes impérios, como o canato mongol, se baseavam nos laços interpessoais entre
} 
O percurso inverso também foi impulsionado, como demonstram as viagens de Rabban Bar Sauma (1287-1288) e Buscarello de Ghisolfi (1289-1290), embaixadores do soberano mongol da Pérsia que visitaram algumas cidades europeias, incluindo Paris e Roma. O próprio Raimundo Lúlio transitava por essas duas localidades naquele exato momento e é possível que tenha assistido aos encontros diplomáticos. Ele estava bem informado sobre o avanço dos mongóis, os quais a Igreja e as monarquias ocidentais buscavam converter e a quem queriam se aliar. ${ }^{11}$ Aliás, foi na Cidade Eterna que Lúlio escreveu, em 1288, o Livro do tártaro e o cristão (GAYÀ ESTELRICH, 1997, p. 41-45; COSTA, 2018, p. 124-133). Mais tarde, quando ouviu a notícia de que os mongóis haviam atacado a Síria, o filósofo partiu imediatamente para o Mediterrâneo oriental (1301), com a intenção de cristianizá-los, o que nunca aconteceu (LÚLIO, 2004, VIII, § 33, p. 87-88). Em sua visão, os mongóis eram indiferentes em relação à religião e controlavam um território que já estava dividido entre três imperadores, dos quais o mais poderoso - o Grande Khan - possuía as terras do Preste João (BORRÁS RULLÁN, 1909, p. 8-9). Repetidas vezes, ele lamentou o fato de os cristãos serem uma minoria cercada pelos "infiéis".

Como sabemos que a história global não pode prescindir de abordar obstáculos e resistências a conexões e integrações (MALERBA, 2019, p. 469), vejamos um momento crucial: o embargo papal (1291-1344) ao comércio dos latinos com os mamelucos egípcios, que dominavam a Palestina. Todavia, estudos recentes concluem que tal proibição não deve ser superestimada. Portos cristãos como Ayas - aliás, ponto inicial/final da Rota da Seda -, onde Lúlio inclusive esteve (1301), passaram a ter cada vez mais importância. Além disso, havia a atuação de intermediários como os bizantinos no Chipre, que não se preocupavam com as determinações pontifícias (JACOBY, 2017, p. 33). Por sinal, os próprios mercadores europeus faziam "ouvidos moucos". Em 1305, Lúlio se referiu a essa insistência dos latinos, defendendo a interceptação do "comércio de especiarias" provenientes do Egito e a excomunhão e o confisco dos bens de "qualquer cristão audacioso" que violasse as proibições (LÚLIO, 2009a, II, 5, p. 81). ${ }^{12}$

A seguir, recomendamos a utilização de um mapa que produzimos com base na totalidade cartográfica do Atlas Catalão e em indicações do próprio Lúlio. Esse simples modelo expõe, por exemplo, o Império Mongol e as Rotas Transaariana e da Seda, servindo como suporte para discutir o impacto dessa potência militar e destacar algumas conexões globais dos séculos XIII a XIV. Sugerimos que ele seja incrementado. Com a orientação do educador, os alunos podem usar diferentes cores para representar nele a composição religiosa (cristianismo, islamismo, budismo etc.) do espaço afro-euroasiático, além do deserto do Saara, que não era uma barreira física às conexões. ${ }^{13}$ Isso pode ser feito na lousa ou no chão da quadra da escola,

soberanos, governadores e vassalos" (CONRAD, 2019, p. 154-155). Sobre o tema, ver Latour (2012). 11 "Pois setenta anos já se passaram desde que os tártaros [mongóis] desceram das montanhas e dominam mais o mundo que os sarracenos e os cristãos juntos” (LÚLIO, 2009a, I, 5, p. 63).

${ }^{12}$ Lúlio ainda sugeria a criação de uma rota comercial direta até a Índia, enfraquecendo economicamente os mamelucos. Assim, "os cristãos, como agora os genoveses e os catalães, passariam a comprar especiarias em Bagdá e na Índia, além da terra do sultão” (LÚLIO, 2009a, II, 5, p. 81). A frase demonstra conexões globais e a importância desses "circuitos comerciais" orientais (ABU-LUGHOD, 1989, p. 34). ${ }^{13}$ No Romanç d'Evast e Blaquerna (1276-1283), Lúlio se refere a uma "cidade que se chama Gana", cuja numerosa população era composta por "negros" que "adoravam ídolos, o sol, as estrelas, as aves 
usando gizes coloridos. Nesse procedimento, que valoriza o papel do discente na construção do conhecimento, o diálogo interdisciplinar com o professor de geografia seria fundamental, com a discussão de conceitos como espaço e fronteira (MOLINA, 2013, p. 80-82). Mas uma ressalva: o material não deve ser introduzido apenas para ilustrar o tema ou situar os alunos espacialmente. Devemos tomá-lo como uma fonte. No caso do Atlas Catalão, como um documento do fim do século XIV, o qual, portanto, não pode ser julgado como "errado" em si. Ou seja, de nada adianta constatar que parte da África está ausente se não houver uma reflexão sobre a razão disso. Suas características têm seus porquês, revelam o imaginário de uma época e precisam ser contextualizadas (CHAMBOULEYRON, 2014, p. 36-37).

Figura 5 - O mundo de Raimundo Lúlio

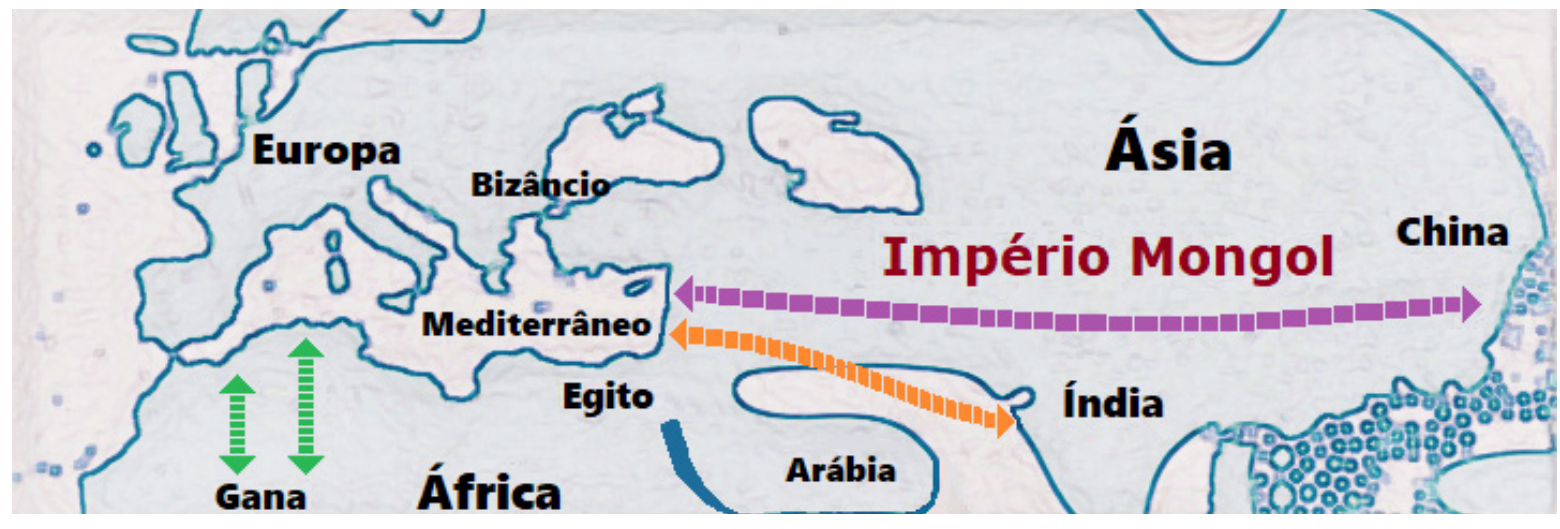

Legenda: Rota Transaariana (verde) / Rota da Seda terrestre (roxo) / Rota sugerida por Lúlio (laranja). Fonte: adaptação do Atlas Catalão publicada por Iman Ghosh em Visual Capitalist (12/07/2019). Disponível em: https://www.visualcapitalist.com/shape-of-the-world-ancientmaps/. Acesso em: 10 fev. 2020.

Voltemos, porém, aos quadrinhos selecionados, que ainda representam a escravidão na Idade Média. Sem dúvida, a vida de Lúlio não pode ser entendida plenamente sem uma referência ao episódio em que ele, com o propósito de aprender árabe, comprou um cativo muçulmano. Eles estudaram juntos por nove anos, até o escravo tentar assassinar o filósofo e, em seguida, cometer suicídio. A escravidão medieval é uma temática desvalorizada por vários livros didáticos (SILVA, 2011, p. 17), em detrimento da servidão (europeia), embora fosse recorrente no mundo mediterrânico sob a forma doméstica. ${ }^{14} \mathrm{~A}$ prática já envolvia os negócios da família de Lúlio, cujo pai comprou um cativo em 1246. Assim, urge apresentá-la e debatê-la em sala de aula, quer nas escolas, quer nas universidades. ${ }^{15}$

e as bestas" (LÚLIO, 2009b, IV, 84.6, p. 379, tradução nossa). Na Idade Média, eram famosas as rotas de comércio transaariano que, por exemplo, traziam mercadorias (como sal e ouro) da África ocidental para o Mediterrâneo.

${ }^{14}$ Já a BNCC (BRASIL, 2017, p. 420) passou a enfatizar o estudo de "Escravidão e trabalho livre em diferentes temporalidades e espaços (Roma Antiga, Europa medieval e África)".

${ }^{15}$ Alguns episódios são dramáticos. Em 1300, os habitantes da colônia islâmica de Lucera (sul da Itália) foram massacrados e escravizados. Lúlio conhecia essa conjuntura, tanto que pregou aos cativos muçulmanos em Nápoles (1294), e provavelmente fez o mesmo em Lucera. Ver Bonnici (2018). 
Para nos aproximarmos dessa temática, podemos consultar uma obra de Jacques Heers (1983), que detalha a configuração do tráfico cristão. Gênova, cidade que Lúlio frequentou por seis vezes, era uma das protagonistas de uma dinâmica rede comercial que integrava outros espaços, ${ }^{16}$ como o Mar Negro, de onde provinham muitos escravos. Entre os amigos genoveses de Lúlio, estava Perceval Spinola, nobre que praticava o tráfico humano em Caffa, na Crimeia. A importância da escravidão na bacia mediterrânica era tão grande que, no Egito, os mamelucos - originalmente cativos convertidos em mercenários - conseguiram tomar o poder (1250). Histórias conectadas, muitos deles eram eslavos e turcos vendidos no Mar Negro pelos mongóis aos italianos, que, por sua vez, os revenderam no Mediterrâneo ao sultão egípcio.

Figura 6 - Raimundo Lúlio e o escravo muçulmano

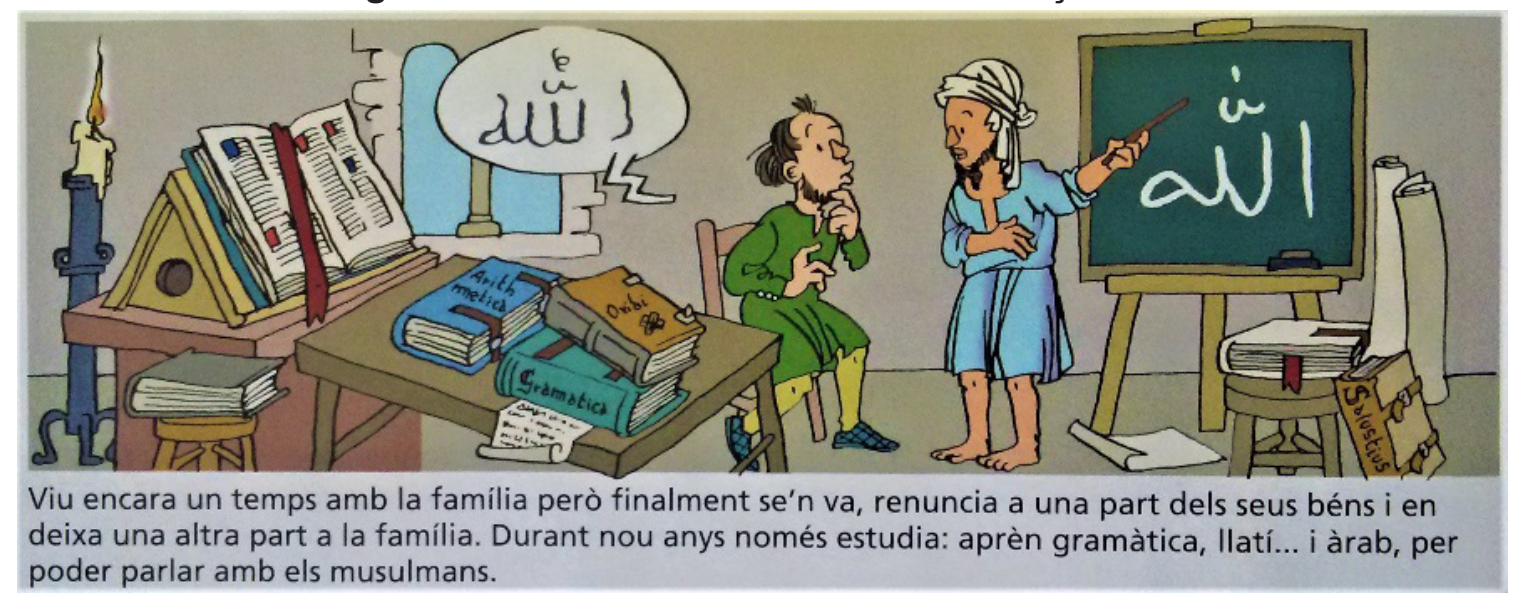

Legenda: "Ele [Lúlio] vive ainda um tempo com a família, mas finalmente vai embora, renuncia a uma parte de seus bens e deixa outra para a família. Durante nove anos, somente estuda: aprende gramática, latim... e árabe, para poder falar com os muçulmanos".

Fonte: revista Cavall Fort (2016, p. 18, tradução nossa). Ilustração: Laura de Castellet.

Vemos uma representação da convivência entre Lúlio e seu escravo no quadrinho acima. Nele, o muçulmano explica o conceito de "Deus" (Allah) na lousa, objeto familiar ao alunado contemporâneo, mas anacrônico àquele contexto. ${ }^{17}$ Além de explicar esse problema, o docente tem a chance de analisar como se deu a caracterização desse "professor-escravo", que porta um turbante, tem a pele morena e aparece de forma simplória (com os pés descalços), ao mesmo tempo que detém conhecimentos que faltavam ao "aluno Raimundo". Embora carregue anacronismos e estereótipos, o quadrinho representa um encontro confirmado na documentação (LÚLIO, 2004, II, $\S 11$, p. 62). De fato, as trocas culturais, mesmo em condições de tensão como as Cruzadas, ocorreram durante todo o Medievo - cristãos e muçulmanos não trocavam apenas golpes de lança e espada...

Passemos agora à adaptação, o outro suporte que sugerimos para trabalhar com a figura de Lúlio em sala de aula. Podemos defini-la como um texto reescrito e reelaborado, a fim de atender a determinado público. Segundo especialistas atuais, as

\footnotetext{
16 "Gênova esteve, durante séculos, profundamente enredada nos circuitos transnacionais" (CONRAD, 2019, p. 165). Diversas viagens de Lúlio pelo Mediterrâneo foram a bordo de navios genoveses.

${ }^{17}$ Para uma historicidade mais precisa, veja uma miniatura do Breviculum (ver Bibliografia), manuscrito produzido entre 1321 e 1330 que representa algumas etapas da vida de Lúlio.
} 
adaptações devem ser versões simplificadas e resumidas, mas sem perder de vista a essência do original. Nenhuma criança ou adolescente precisa ler o texto integral: "O ideal mesmo é uma adaptação bem-feita e atraente" (MACHADO, 2002, p. 15). Algo relevante a salientar é que ela não tem o poder de substituir o original; "atua como uma introdução, pois apresenta a obra aos leitores ainda claudicantes" (FORMIGA, 2011, p. 54). As adaptações das obras de Lúlio surgiram no início do século $X X$, começando com - Livro das bestas (Figura 7), cuja aplicabilidade em sala de aula indicamos a seguir.

Figura 7 - Capa do Libro de las Bestias

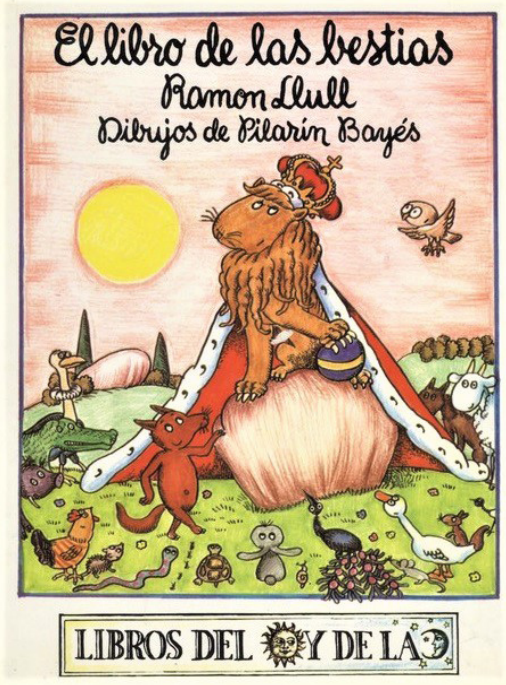

Fonte: Adaptação de Aurora Díaz Plaja. Ilustrações de Pilarín Bayés. Barcelona: Ultramar Editores, 1986.

Finalizado em Paris (c. 1288), o Livro das bestas tem marcantes influências orientais, como fábulas indianas (Kalila e Dimna), que chegaram ao Mediterrâneo ocidental via transmissão e tradução árabe (PUIG MONTADA, 2008, p. 513). Uma verdadeira translação "global" de saberes, o que alguns acadêmicos chamaram de Translatio Studiorum (LEÓN FLORIDO, 2005). Na Península Ibérica, o Kalila e Dimna foi traduzido para o castelhano (1251) por ordem do infante Afonso, futuro "rei sábio" de Leão e Castela. É muito possível que isso tenha ocorrido na famosa Escola de Tradutores de Toledo, onde atuavam sobretudo sábios judeus e cristãos. Não podemos afirmar, contudo, que Lúlio tenha conhecido a fábula indiana por meio dessa tradução ou de um manuscrito árabe, língua que ele já dominava naquela época. Seja como for, cerca de um terço dos contos do Livro das bestas é procedente do Kalila e Dimna, ainda que reelaborados (MARTíN PASCUAL, 2013, p. 83-86). Trata-se, em resumo, de um fenômeno transcultural que fundiu e entrelaçou elementos diversos.

A narrativa luliana gira em torno da Raposa, que se vale de táticas sorrateiras para manipular os animais (o Boi, o Elefante, o Coelho, o Pavão etc.) e angariar a posição de única conselheira do rei Leão, alvo que ela planejava eliminar. É provável que Lúlio pretendesse compor um "espelho de príncipes", indicando os perigos que cercavam o governante francês daquela época e as qualidades morais que deveria cultivar. De maneira metafórica, ele constrói uma crítica à sociedade dos homens, o animal "mais falso existente neste mundo" (LÚLIO, 1990, IV, p. 82). A figura de linguagem era muito aplicada pelos autores medievais, como Lúlio, que lança mão em 
suas obras da metáfora dos animais, do corpo, da árvore, entre outras. Temos, nesse caso, um precioso recurso que facilita a compreensão de abstrações conceituais. ${ }^{18}$

Até o momento, o Livro das bestas conta apenas com adaptações infantojuvenis em catalão e espanhol. Em razão disso, sugerimos que o docente traduza para o português uma dessas edições, como a de Aurora Díaz Plaja (1986). Ela segue uma tendência verificada em adaptações catalãs produzidas durante o Any Llull, que não expuseram os 28 exempla do original. ${ }^{19}$ Tais versões introduziram imagens e simplificaram o texto em busca de linearidade, por isso são mais indicadas para o público infantil. Já aquelas detentoras da totalidade dos exempla devem ser trabalhadas com o público juvenil, que tem maior capacidade de abstração e mais possibilidade de evitar uma interpretação literal da narrativa. Todas essas adaptações almejam transmitir a mensagem de que o governo ideal deveria ser guiado por indivíduos com condutas dignas de serem imitadas (SELFA SASTRE, 2019, p. 77).

Para introduzir a adaptação do Livro das bestas no ambiente escolar, podemos recorrer à leitura e à teatralização da obra. Nessa ocasião, o professor tem a chance de instigar os alunos a imaginarem os personagens e as cenas, a formularem questões e a refletirem acerca do contexto e da história. As alianças e as disputas entre os animais, que representam distintos grupos do reino, variam segundo os interesses e as posições que ocupam em relação ao monarca. Em sala de aula, elas podem servir para uma aproximação aos problemas sociais medievais (MACEDO, 2003, p. 122-123). Uma abordagem válida também é discutir os principais valores que caracterizam o mundo feudal: honra, fidelidade e hierarquia. Ora, essa é a lógica social predominante no Livro das bestas, cujos personagens reafirmam, no desfecho do enredo, a supremacia de concepções como fidelidade ao senhor e ao estamento vigente (BUTIÑÁ JIMÉNEZ, 2004, p. 88). Isso pode ser notado em certos episódios, como quando o Elefante se arrepende e desiste de trair o rei Leão. ${ }^{20}$

Outra obra luliana que indicamos é o Livro do gentio e dos três sábios (Figura 8). Nesse texto redigido em Maiorca (c. 1274-1283), Lúlio relata a história de um sábio (o gentio) que passava por uma crise existencial: "Não tinha qualquer conhecimento de Deus, nem acreditava na ressurreição, ou na existência de qualquer coisa depois da morte" (LÚLIO, 2001, Prólogo, p. 42). Enquanto caminhava por um bosque, o angustiado personagem encontra os sábios das três grandes religiões monoteístas (cristianismo, islamismo e judaísmo), que Ihe explicam suas respectivas crenças. Ele deveria se converter a uma delas. ${ }^{21} \mathrm{O}$ livro do gentio e dos três sábios pode ser introduzido sob a forma da adaptação de Ignasi Moreta, que já foi traduzida para o português (2016). Ela mantém a essência da versão integral, com um texto resumido e sem as intricadas explicações dos "artigos de fé" das três religiões abraâmicas. No fim, oferece um guia de leitura com seis tópicos, como "Para ajudar a refletir", dentro do qual temos oito perguntas.

\footnotetext{
18 "A metáfora é o principal mecanismo pelo qual compreendemos conceitos abstratos e realizamos raciocínios abstratos" (LAKOFF, 1993, p. 244, tradução nossa).

${ }^{19}$ Muito populares no século XIII, os exempla eram contos breves com os quais se buscava ensinar, edificar e convencer um auditório.

20 "Mas a cada dia era maior o pânico que [o Elefante] sentia diante do rei Leão, e por nada no mundo ele queria tentar destroná-lo ou substituí-lo" (1986, s/p, tradução nossa).

${ }^{21}$ No fim desse livro, Lúlio não indica explicitamente a escolha do gentio, o cristianismo, conforme aponta noutras obras, como no Livro derradeiro (LÚLIO, 2009a, I, 5, p. 59).
} 
Figura 8 - Capa do Livro do gentio e dos três sábios

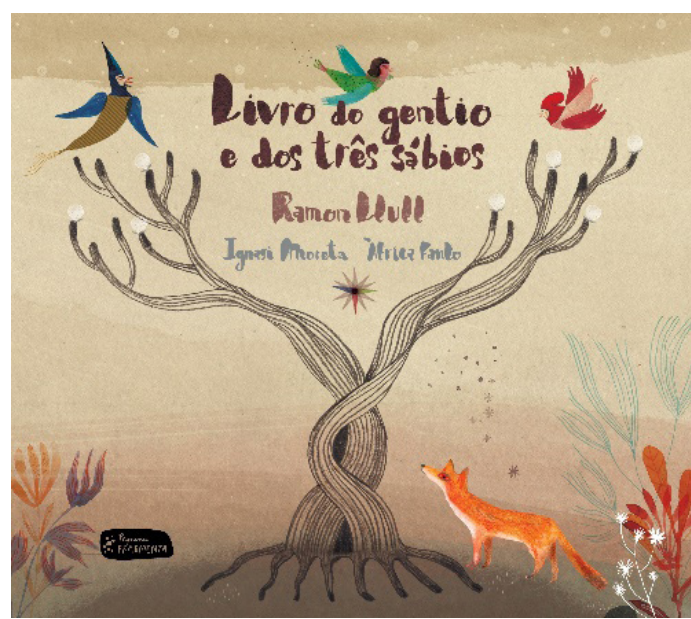

Fonte: Adaptação de Ignasi Moreta. Ilustrações de Àfrica Fanlo.

Barcelona: Pequena Fragmenta, 2016.

A leitura e a teatralização da obra, que sugerimos para o Livro das bestas, igualmente pode ser praticada, com quatro grupos de estudantes representando os personagens (o gentio, o judeu, o muçulmano e o cristão), seus respectivos diálogos e comportamentos. Numa leitura em conjunto, ${ }^{22}$ recomendamos que o educador discuta com eles a diversidade cultural e religiosa medieval, que Lúlio presenciou em vários territórios pelos quais percorreu, sobretudo no mundo mediterrânico. Certamente, o conceito de "Idade Média monoteísta" é menos problemático do que o antigo "Idade Média cristã" (BORGOLTE, 2017, p. 75; 78):

Era uma vez um gentio, quer dizer, um homem que não praticava nenhuma religião. [...] Entretanto, três sábios encontraram-se à saída de uma cidade. Um era judeu, o outro cristão e o terceiro muçulmano. Ao verem-se, cumprimentaram-se mutuamente e decidiram acompanhar-se. Cada um falava aos outros dois sobre a sua crença e os seus pensamentos, e falando, falando, chegaram ao bosque por onde andava o gentio (2016, s/p).

A relação amistosa entre um cristão, um muçulmano e um judeu descrita no Livro do gentio e dos três sábios, mesmo sendo ficcional, pode funcionar como ponto de partida para demonstrar a complexidade, em solo ibérico, dos contatos entre esses credos. Por outro lado, precisamos lembrar o "mito da tolerância" no Medievo hispânico, porque nunca houve uma convivência com base em relações em pé de igualdade e plena aceitação das diferenças (GARCÍA FITZ, 2002, p. 155). Além disso, não pretendemos instrumentalizar a figura de Lúlio para priorizar ou exaltar alguma das facetas (ecumênico, tolerante, pacifista) que já Ihe foram atribuídas (PARDO PASTOR, 2004, p. 441-442). Sabemos que outras obras lulianas chegaram

\footnotetext{
22 "Ler a história com a entonação adequada torna o interesse do aluno maior; quanto mais teatral e lúdica for a performance e interpretação do narrador, melhor será o rendimento e a conexão com o ouvinte, quanto maior a ênfase na fala dos personagens, mais interessados e estimulados irão ouvir a história" (ANTUNES; OLIVEIRA, 2017, p. 28).
} 
a admoestar o islamismo e o judaísmo, a propor a criação de uma ordem militar e a pregar uma cruzada para a conquista de Jerusalém, porém isso não é razão suficiente para deixar de utilizar sua extraordinária trajetória e seu pensamento como um guia valioso para a compreensão do período medieval.

\section{CONSIDERAÇÕES FINAIS}

Nossa pesquisa articulou a Idade Média global ao ensino de história tomando como referência o filósofo maiorquino Raimundo Lúlio. Existem outras possibilidades - Ibn Battuta é uma delas. Esse viajante muçulmano marroquino, que nasceu no início do século XIV, tanto nos afasta do viés eurocêntrico quanto nos aproxima da história global. Ele percorreu milhares de quilômetros, principalmente pelo mundo islâmico, e sua viagem à África ocidental foi estudada num projeto didático-pedagógico desenvolvido na Universidade Federal do Rio Grande do Sul (UFRGS) entre 2008 e 2010. Entre os resultados dessa pesquisa, estão um documentário, que chegou a ser exibido em escolas municipais da região metropolitana de Porto Alegre (DOCUMENTÁRIO, 2010), e um livro destinado aos alunos do Ensino Fundamental e Médio.

Guiados por Raimundo Lúlio, não só percorremos espaços integrados e conectados, cruzamos fronteiras fluidas e dinâmicas, como também observamos diversidades culturais e religiosas marcantes e o aparecimento de fenômenos transculturais. Seguindo os passos desse filósofo, homem cosmopolita e mediterrânico que se considerava um arabicus christianus, ${ }^{23}$ contribuímos para uma renovação do ensino da Idade Média. Esse Medievo não gira mais em torno da Europa, o centro do mundo, como imaginam seus detratores e enaltecedores, além daqueles historiadores que redigiram a primeira versão da BNCC. Na realidade, estamos diante de um contexto multicêntrico no qual o próprio continente europeu esteve por vezes prestes a ser engolido por forças provenientes de regiões que ele pouco conhecia, como as estepes asiáticas. Lúlio foi testemunha disso.

Em especial desde o Any Llull, temos à disposição HQs e muitas adaptações infantojuvenis de seus textos, com potencial para serem introduzidas em sala de aula. Numa perspectiva interdisciplinar, várias atividades ainda são possíveis, entre as quais a proposição de um concurso de redação de fábulas baseadas nas obras lulianas e a produção de outros quadrinhos. ${ }^{24}$ Para finalizar, sugerimos a elaboração de mais um material didático, inspirado num quadrinho da revista Cavall Fort nesse caso, um desenho da Arte luliana num disco giratório (Figura 9). Referimonos a duas adaptações desse disco (Figura 10 e Quadro 1, com dois breves relatos de experiência), cujo exercício de combinação pode estimular o raciocínio lógico e conduzir ao entendimento de aspectos da trajetória de Lúlio e de seu contexto medieval. Em suma, existem múltiplas e criativas possibilidades para explorar esse fascinante personagem.

\footnotetext{
${ }^{23}$ Tal expressão consta, por exemplo, no Livro derradeiro. Na edição moderna (catalão-português) que consultamos (LÚLIO, 2009a, I, 2, p. 42), lemos "cristians àrabs", tradução do original latino citado.

${ }^{24}$ Para a produção de HQs, consulte Vilela (2014, p. 128-129).
} 
Figura 9 - Raimundo Lúlio e a Arte luliana

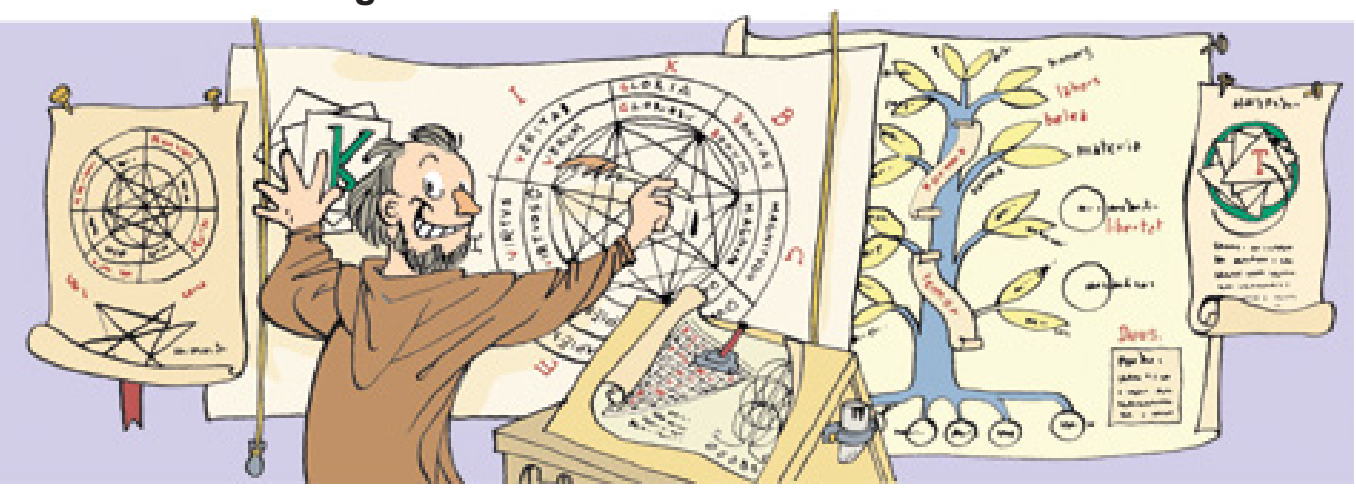

Fonte: Revista Cavall Fort (2016, p. 19). Ilustração: Laura de Castellet.

Figura 10 - Arte luliana (adaptação): material didático
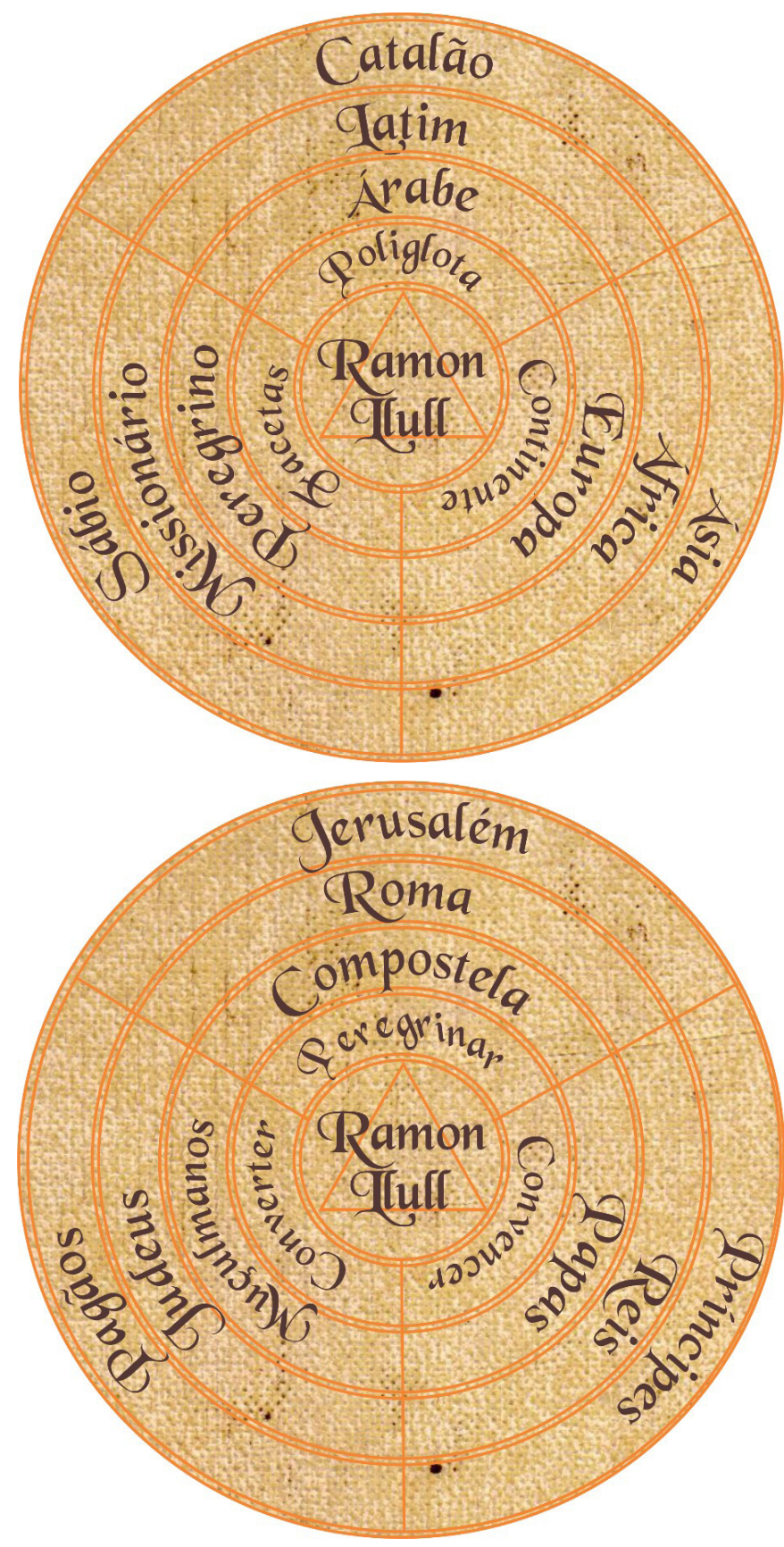
Figura 10 - Arte luliana (adaptação): material didático (continuação)
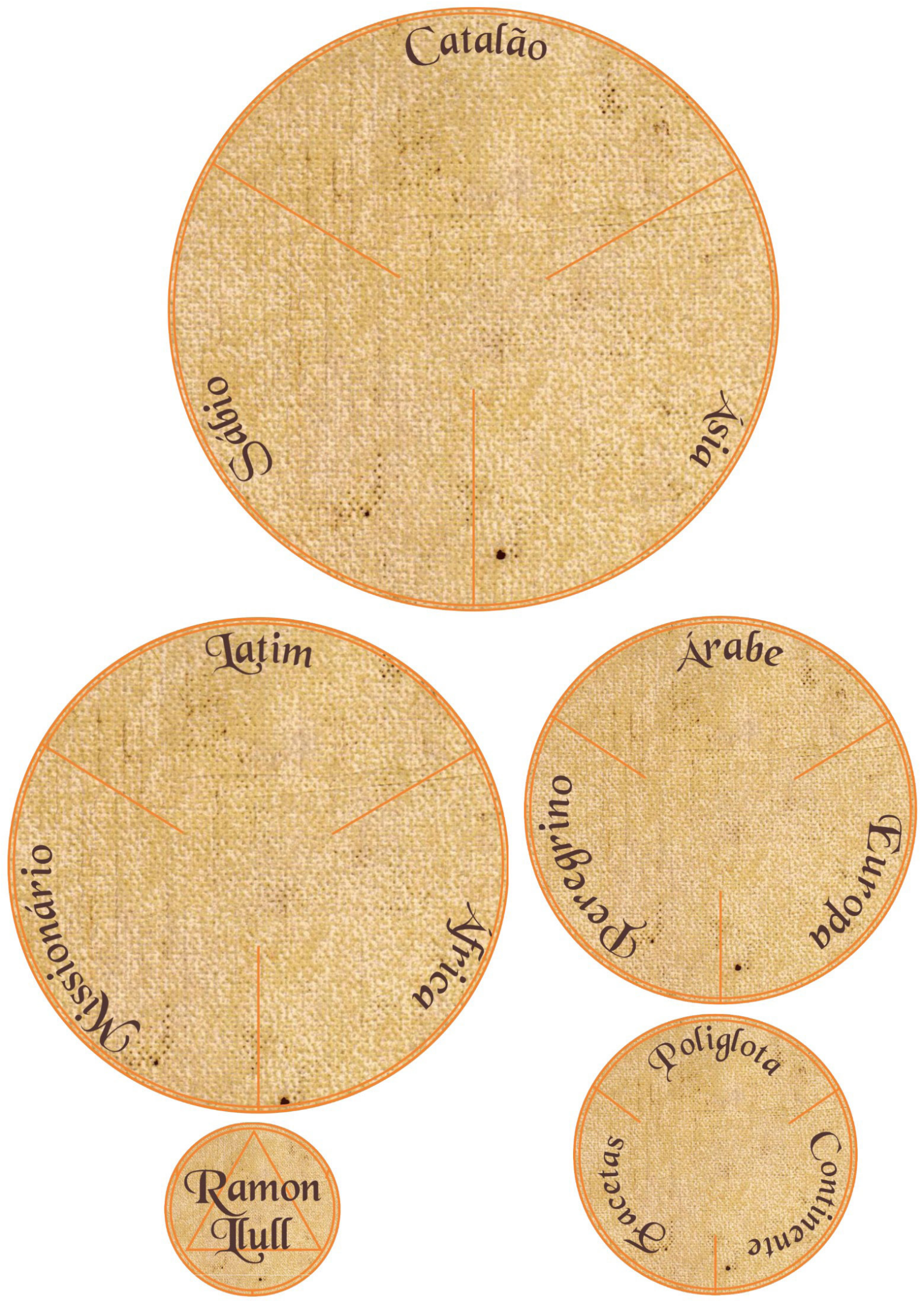
Figura 10 - Arte luliana (adaptação): material didático (continuação)
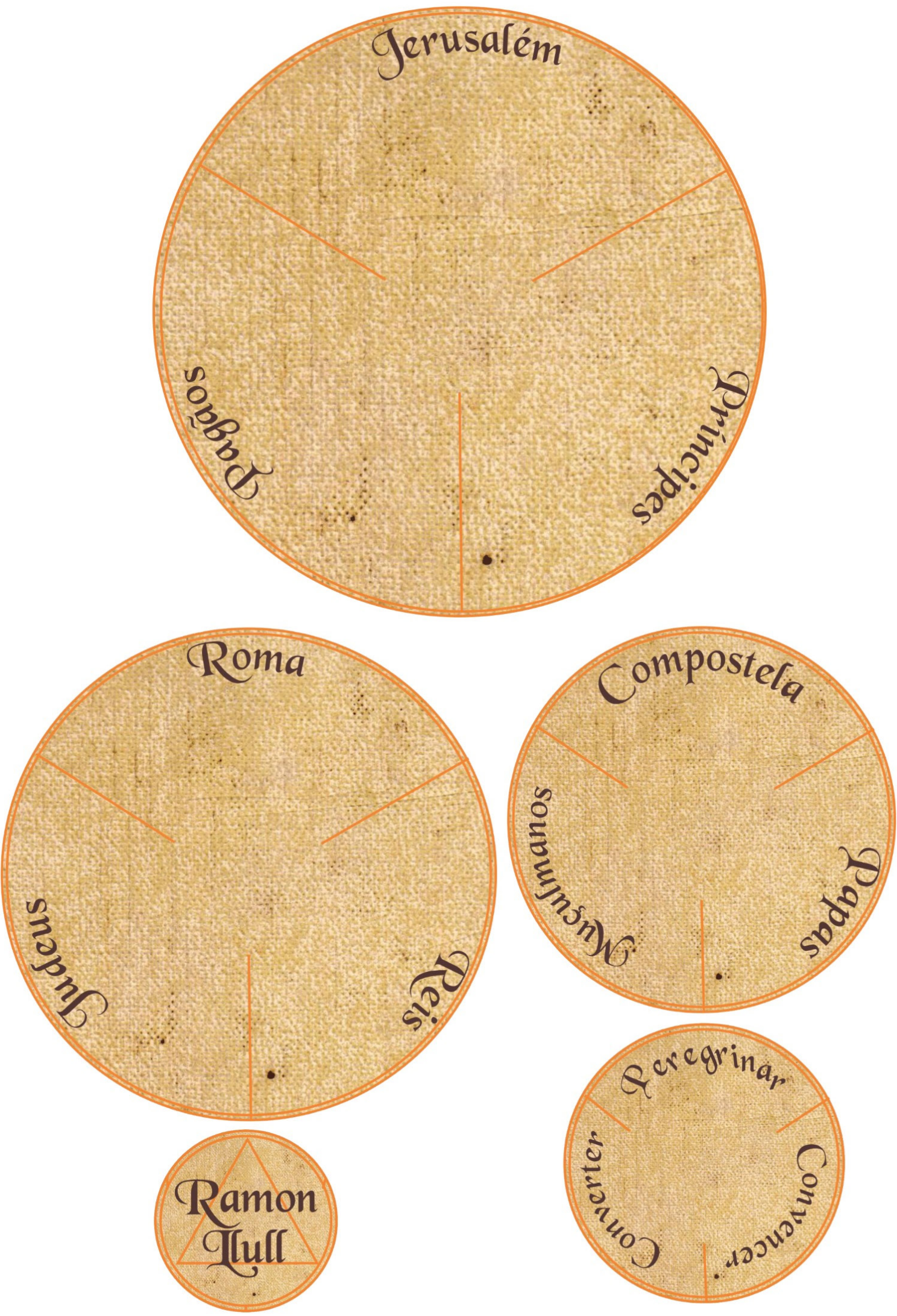
Quadro 1 - Arte Luliana (adaptação) ${ }^{25}$

\section{Instruções para a produção e a utilização do material didático}

1) Imprima os modelos das duas páginas acima, de preferência em tamanhos maiores;

2) Cole-os em folhas de papelão e recorte-os;

3) Sobreponha os discos, perfure-os no centro e fixe-os com um parafuso de plástico.

Atividade para o Ensino Fundamental. Após as orientações sobre o contexto histórico, solicite a leitura da Auca de Ramon Llull. Depois, desmonte a combinação dos discos, entregue aos alunos e instigue-os a descobri-la. Ao fim, explique a combinação correta.

Relatos de experiência ${ }^{25}$

Professora: Letícia Herculano da Silva Alves (Pivic-UFPB)

Aluna: 12 anos, $7^{\circ}$ ano

Orientações sobre o contexto: 15 minutos

Tempo de leitura da Auca: 10 minutos

Tempo de combinação dos discos: 5 minutos

\section{Dificuldades:}

- Diferenciar as palavras "convencer" e "converter".

- Não conhecia algumas localidades referidas na HQ.

- Não sabia da existência do idioma catalão.

\section{Destaques:}

- Já conhecia a relevância econômica do Mediterrâneo medieval.

- Já sabia da existência de povos não cristãos no Medievo, mas só conhecia alguns fatos da Europa ocidental.

- Maior interesse pela atividade após perceber que se tratava de uma $\mathrm{HQ}$.

- Maior interesse pela Idade Média após a atividade.

Professora: Laryssa Alves da Silva (Pibic-UFPB)

Aluno: 13 anos, $7^{\circ}$ ano

Orientações sobre o contexto: 10 minutos

Tempo de leitura da Auca: 8 minutos

Tempo de combinação dos discos: 5 minutos

\section{Dificuldades:}

- Não conhecia algumas localidades referidas na HQ.

- Não compreendia bem as diferenças entre os continentes.

- Disse não ter estudado ou não se lembrar dos conteúdos sobre o Medievo.

\section{Destaques:}

- Associava o período medieval apenas à história da Europa.

- Não sabia que existiam distintos povos e religiões na Idade Média além dos cristãos europeus.

- Maior interesse pela Idade Média após a atividade.

\footnotetext{
${ }^{25} \mathrm{~A}$ pandemia de Covid-19 infelizmente impossibilitou a realização da atividade em grupos, dentro ou fora das escolas, o que não invalida os resultados. Além da boa receptividade do exercício, destacamos seu potencial em desconstruir uma suposta unidade religiosa e cultural (cristã europeia) do período medieval.
} 


\section{REFERÊNCIAS}

A HISTÓRIA DE RAMON LLULL (1232-1316) EM QUADRINHOS. Adaptação para o português: Tatyana Nunes Lemos. Revisão final: Ricardo da Costa. Disponível em: https://www.ricardocosta.com/historia-de-ramon-llull-1232-1316-em-quadrinhos. Acesso em: 20 mar. 2020.

ABULAFIA, David. Mediterranean History as Global History. History and Theory, Middletown, v. 50, n. 2, p. 220-228, 2011.

ABU-LUGHOD, Janet. Before European Hegemony: The World System A.D. 12501350. Nova York: Oxford University Press, 1989.

ALMEIDA, Néri de Barros; DELLA TORRE, Robson (org.). O Mediterrâneo medieval reconsiderado. Campinas: Editora da Unicamp, 2019.

ANTUNES, Tiana Andreza Melo; OLIVEIRA, Thaís Martins de. A literatura infantil em sala de aula nos anos iniciais: a importância dos contos. Revista de Letras, Curitiba, v. 19, n. 26 , p. 16-33, 2017.

APOLINÁRIO, Maria Raquel. Projeto Araribá: História. São Paulo: Moderna, 2014.

AUCA DE RAMON LLULL. Texto: Joan Vilamala. Ilustrações: Jaume Gubianas. Manacor: Ajuntament de Manacor, 2003. Disponível em: http://www.auques.cat/auca. php?auca=llull. Acesso em: 27 mar. 2020.

BAYARD, Adrien; BOVO, Cláudia Regina. Histórias conectadas da Idade Média: abordagens globais antes de 1600. Esboços, Florianópolis, v. 27, n. 44, 2020.

BONNICI, Thomas. De Mazara a Lucera: os muçulmanos na Sicília, em Malta e na Itália, 827-1300. Maringá: Massoni, 2018.

BORGOLTE, Michael. A Crisis of the Middle Ages? Deconstructing and Constructing European Identities in a Globalized World. In: LOUB, Graham A.; STAUB, Martial (ed.). The Making of Medieval History. York: York Medieval Press, 2017. p. 70-84.

BORRÁS RULLÁN, J. Lo que dice el Bto. Ramón Lull de los Mongoles o Tártaros. Boletí de la Societat Arqueológica Luliana, Palma de Mallorca, v. 12, p. 7-10, 1909.

BRASIL. Ministério da Educação. Secretaria da Educação Básica. Base Nacional Comum Curricular. Brasília: MEC, 2017. Disponível em: http://basenacionalcomum. mec.gov.br/images/BNCC_EI_EF_110518_versaofinal_site.pdf. Acesso em: 15 mar. 2020.

BREVICULUM. Karlsruhe, Badische Landesbibliothek, Cod. St. Peter perg. 92, fol. 3v. Disponível em: https://digital.blb-karlsruhe.de/blbhs/content/pageview/105546. Acesso em: 27 mar. 2020. 
BUTIÑÁ JIMÉNEZ, J. Sobre el escandaloso "Llibre de les bèsties" de Ramón Llull y su audiencia. Espacio, Tiempo y Forma, Serie III, Historia Medieval, Madri, n. 17, p. 79-94, 2004.

CHAMBOULEYRON, Rafael. Os historiadores e os mapas. Perspectivas de pesquisa e ensino. In: HENRIQUE, Marcio Couto (org.). Diálogos entre história e educação. Belém: Editora Açaí, 2014. p. 35-67.

CONRAD, Sebastian. O que é a História Global? Lisboa: Edições 70, 2019.

COSTA, Ricardo da. Ramon Llull (1232-1316) foi o filósofo da tolerância na Idade Média? O Livro do Tártaro e o Cristão (1288). In: SALATINI, Rafael; DIAS, Laércio Fidélis (org.). Reflexões sobre a Paz. Marília: Oficina Universitária, 2018. p. 115-138. v. 2.

CRESQUES, A. Atlas Catalão, Ms. Esp. 30, Bibliothèque nationale de France, 1375. Wikimedia Commons. Disponível em: https://upload.wikimedia.org/wikipedia/ commons/3/3b/El_mar_Mediterr\%C3\%A1neo_en_el_Atlas_catal\%C3\%A1n_de_ Cresques_Abraham.jpg. Acesso em: 15 mar. 2020.

DOCUMENTÁRIO de Ibn Battuta é exibido em escolas. Portal da PROREXT - UFRGS, 2010. Disponível em: http://www.ufrgs.br/prorext-siteantigo/news/ documentario-de-ibn-battuta-e-exibido-em-escolas. Acesso em: 20 mar. 2020.

EL HISTORIADOR y escritor Gaspar Valero visita La Salle Palma para inaugurar una exposición sobre Ramon Llull, Colegio La Salle Palma, 2016. Disponível em: http:// www.lasallevalenciapalma.es/historiador-escritor-gaspar-valero-visita-la-salle-palmainaugurar-una-exposicion-ramon-Ilull/. Acesso em: 15 mar. 2020.

ENLLULLA'T. Programa Educatiu sobre Ramon Llull - Unitats Didàctiques. enLLULLa't, 2016. Disponível em: http://enllullat.cat/. Acesso em: 10 mar. 2020.

FORMIGA, Girlene Marques. As várias formas de ler clássicos literários: uma proposta com as adaptações. In: BARBOSA, Socorro de Fátima Pacífico (org.). Ensinar literatura através projetos didáticos e de temas caracterizadores. João Pessoa: Editora da UFPB, 2011. p. 25-57.

FRANKOPAN, Peter. Why We Need to Think About the Global Middle Ages. Journal of Medieval Worlds, Berkeley, v. 1, n. 1, p. 5-10, 2019.

GARCÍA FITZ, F. ¿La "España de las tres culturas"? El tópico de la tolerancia y los límites de la coexistencia en la España medieval. In: JESÚS MERINERO, M. (coord.). Diálogo de Civilizaciones Oriente-Occidente. Cáceres: Universidad de Extremadura, 2002. p. 127-155.

GARCÍA ESPADA, A. El Imperio Mongol. Madrid: Editorial Síntesis, 2017. 
GARCÍA SANJUÁN, A. Cómo desactivar una bomba historiográfica: la pervivencia actual del paradigma de la Reconquista. In: AYALA MARTÍNEZ, C. de et al (coord.). La Reconquista: Ideología y justificación de la Guerra Santa peninsular. Madrid: La Ergástula Ediciones, 2019. p. 99-119.

GAYÀ ESTELRICH, J. Ramon Llull en Oriente (1301-1302): circunstancias de un viaje. Studia Lulliana, Palma de Mallorca, v. 37, p. 25-78, 1997.

GEARY, Patrick. O mito das Nações: a invenção do nacionalismo. São Paulo: Conrad Editora do Brasil, 2005.

HEERS, Jacques. Escravos e domésticos na Idade Média no mundo mediterrâneo. São Paulo: Difel, 1983.

HERMANS, Erik. Introduction. In: HERMANS, Erik (ed.). A Companion to the Global Early Middle Ages. Leeds: Arc Humanities Press, 2020. p. 01-12.

HILLGARTH, Jocelyn Nigel. Ramón Llull y el lulismo en la Francia del siglo XIV. Barcelona: Institut d'Estudis Catalans, 2018.

HOLMES, Catherine; STANDEN, Naomi. Defining the Global Middle Ages. Medieval Worlds, Viena, n. 1, p. 106-117, 2015.

JACOBY, David. Western commercial and Colonial Expansion in the Eastern Mediterranean and the Black Sea in the Late Middle Ages. In: ORTALLI, Gherardo; SOPRACASA, Alessio (ed.). Rapporti mediterranei, pratiche documentarie, presenze veneziane: le reti economiche e culturali (XIV-XVI secolo). Veneza: IVSLA, 2017. p. 03-50.

LAKOFF, George. The contemporary theory of metaphor. In: ORTONY, Andrew (ed.). Metaphor and thought. Cambridge: Cambridge University Press, 1993. p. 202-251.

LANGER, Johnni. O ensino de História Medieval pelos quadrinhos. História, Imagem e Narrativas, Rio de Janeiro, v. 8, p. 01-24, 2009.

LATOUR, Bruno. Reagregando o social: uma introdução à teoria do ator-rede. Salvador: Edufba, 2012.

LEE, Peter. Progressão da compreensão dos alunos em História. In: BARCA, Isabel (org.). Perspectivas em Educação Histórica. Actas das Primeiras Jornadas Internacionais de Educação Histórica. Braga: Universidade do Minho, 2001. p. 13-27.

LEÓN FLORIDO, F. Translatio Studiorum: Traslado de los libros y diálogo de las civilizaciones en la Edad Media. Revista General de Información y Documentación, Madri, v. 15, n. 2, p. 51-77, 2005.

LIBRO DE LAS BESTIAS. Adaptação: Aurora Díaz Plaja. Ilustrações: Pilarín Bayés. Barcelona: Ultramar Editores, 1986. 
LIVRO DO GENTIO E DOS TRÊS SÁBIOS. Adaptação: Ignasi Moreta. Ilustrações: Àfrica Fanlo. Tradução para o português: Inês Castel-Branco. Barcelona: Pequena Fragmenta, 2016.

LÚLIO, Raimundo. Livro das bestas. São Paulo: Editora Giordano; Edições Loyola, 1990.

LÚLIO, R. O livro do gentio e dos três sábios. Petrópolis: Vozes, 2001.

LÚLIO, R. Vida coetânea. Coimbra: Ariadne Editora, 2004.

LÚLIO, R. O livro derradeiro. In: Raimundo Lúlio e as Cruzadas. Rio de Janeiro:

Sétimo Selo, 2009a. p. 35-99.

LÚLIO, R. Romanç d'Evast e Blaquerna. Palma de Mallorca: Patronat Ramon Llull, 2009b.

LÚLIO, Raimundo. O livro da disputa entre Pedro e Ramon. In: FEITOSA, Márcia; ZIERER, Adriana (org.). Literatura e História Antiga e Medieval: diálogos interdisciplinares. São Luís: Edufma, 2010. p. 317-338.

MACEDO, José Rivair. Repensando a Idade Média no Ensino de História. In: KARNAL, Leandro (org.). História na sala de aula: conceitos, práticas e propostas. São Paulo: Contexto, 2003. p. 109-126.

MACHADO, Ana Maria. Como e por que ler os clássicos universais desde cedo. Rio de Janeiro: Objetiva, 2002.

MALERBA, Jurandir. História da historiografia e perspectiva global: um diálogo possível? Esboços, Florianópolis, v. 26, n. 43, p. 457-472, 2019.

MARTÍN PASCUAL, L. Huella del Calila e Dimna en la literatura catalana medieval. In: ORTOLA, M.-S. (coord.). Énoncés sapientiels et littérature exemplaire. Nancy: Éditions Universitaires de Lorraine, 2013. p. 83-99.

MATEUS, Natasha Nickolly A. S. Ensino de História Medieval: a obra Doutrina para Crianças, de Ramon Llull e a produção do paradidático "Ramon Llull e a Idade Média”. Dissertação (Mestrado Profissional em História, Ensino e Narrativas) Universidade Estadual do Maranhão, Centro de Educação, Ciências Exatas e Naturais, São Luís, 2018.

MOLINA, Ana Heloisa. Mapas Históricos: alguns apontamentos e uma abordagem pedagógica. In: ALEGRO, Regina Célia et al (org.). Temas e questões para o ensino de história do Paraná. Londrina: Eduel, 2013. p. 65-86.

MOORE, Robert I. A Global Middle Ages? In: BELICH, James; DARWIN, John; FRENZ, Margret; WICKHAM, Chris (ed.). The Prospect of Global History. Oxford: Oxford University Press, 2016. p. 80-92. 
PARDO PASTOR, J. "Diálogo interreligioso" y Edad Media latina. Boletín de la Real Academia de Buenas Letras de Barcelona, Barcelona, v. 49, p. 433-446, 2004.

PEREIRA, Nilton Mullet. Imagens da Idade Média na Cultura Escolar. Revista Aedos, Porto Alegre, v. 2, p. 117-127, 2009.

PUIG MONTADA, J. Ramon Llull and the Islamic culture of the Mediterranean. In: AKASOY, A.; RAVEN, W (eds.). Islamic Thought in the Middle Ages. Leiden: Brill, 2008. p. 503-519.

RAMON LLULL, UN HOME FANTÀSTIC. Dossiê da revista Cavall Fort (n. 12891290). Texto: Mercè Canela e Eugènia Morer. Ilustrações: Lluïsot, Laura de Castellet, Pep Brocal i Quim Bou. Barcelona: Edicions Cavall Fort, 2016.

SELFA SASTRE, Moisés. La transmisión de la ideología medieval en la literatura infantil y juvenil actual: el caso de los exempla de el Llibre de les Bèsties (1289), de Ramon Llull, y sus adaptaciones infantiles y juveniles. Revista de Educação, Ciência e Cultura, Canoas, v. 24, n. 2, p. 71-79, 2019.

SILVA, Edlene. Livros didáticos e ensino de história: a Idade Média nos manuais escolares do Ensino Fundamental. História \& Ensino, Londrina, v. 17, n. 1, p. 7-31, 2011.

SILVA, Marcelo Cândido da. Uma história global antes da globalização? Circulação e espaços conectados na Idade Média. Revista de História da USP, São Paulo, n. 179, 2020.

SILVEIRA, Aline Dias da. História global da Idade Média: estudos e propostas epistemológicas. Roda da Fortuna, Barcelona, v. 8, n. 2, p. 210-236, 2019.

VERGUEIRO, Waldomiro; RAMOS, Paulo. Os quadrinhos (oficialmente) na escola: dos PCN ao PNBE. In: VERGUEIRO, Waldomiro; RAMOS, Paulo (org.). Os quadrinhos na educação: da rejeição à prática. São Paulo: Contexto, 2009. p. 9-42.

VIGOTSKY, Lev Semenovich. A formação social da mente. São Paulo: Martins Fontes, 2007.

VILELA, Marco Túlio. Os quadrinhos na aula de história. In: RAMA, Ângela; VERGUEIRO, Waldomiro (org.). Como usar as histórias em quadrinhos em sala de aula. São Paulo: Contexto, 2014. p. 105-129.

VISITA del Joglar Pau. Colegio La Salle Palma, 2016. Disponível em: https://palma. lasalle.es/visita-del-joglar-pau-a-infantil/. Acesso em: 15 mar. 2020. 


\section{NOTAS DE AUTOR}

\section{ENDEREÇO PARA CORRESPONDÊNCIA}

Avenida Monteiro da Franca, 661, Apto. 1302, 58038-320, João Pessoa, PB, Brasil.

\section{ORIGEM DO ARTIGO}

Projeto de Pesquisa: "Ramon Llull, a Idade Média Global e o Ensino de História: perspectivas de abordagem".

\section{AGRADECIMENTOS}

Agradeço ao professor Ivan Lima Gomes (UFG) pelas sugestões e ponderações sobre as HQs.

\section{CONSENTIMENTO DE USO DE IMAGEM}

Foi obtido o consentimento escrito dos participantes.

\section{APROVAÇÃO DE COMITÊ DE ÉTICA EM PESQUISA}

Não se aplica.

\section{CONFLITO DE INTERESSES}

Não houve conflito de interesses.

\section{LICENÇA DE USO}

(c) Guilherme Queiroz de Souza. Este artigo está licenciado sob a Licença Creative Commons CCBY. Com essa licença você pode compartilhar, adaptar e criar para qualquer fim, desde que atribua a autoria da obra.

\section{PUBLISHER}

Universidade Federal de Santa Catarina. Programa de Pós-Graduação em História. Portal de Periódicos UFSC. As ideias expressadas neste artigo são de responsabilidade de seus autores, não representando, necessariamente, a opinião dos editores ou da universidade.

\section{EDITORES}

Flávia Florentino Varella (Editora-chefe)

Tiago Kramer de Oliveira

Waldomiro Lourenço da Silva Júnior

\section{HISTÓRICO}

Recebido em: 31 de agosto de 2020

Aprovado em: 8 de março de 2021 